搔爬の治療方法には賛同致します. 年少児 (10才以 下）や腰仙移行部の場合, 又, 多椎体に亘る場合には （移植骨に肋骨を用いた場合）等には, 前方固定術後 に，3 週〜 4 週の間隔にて posterior spinal fusion を行なった方が, より安全であり, 早期離床が出来る と思いますが如何でしょうか.
1. 宮崎教授に対し, 脊椎カリエスに対する前方固 定術の手術時期に関しては出来るだけ早期手術を行な っており，特に脊髄麻瘦を呈したものでは早期手術を 要すると考えます.

2. 脊椎カリエス前方直達手術後, 後方固定の必要 性に関して現在その様な症例はないが, 追加発言で云 われた様な症例で骨移植固定が出来ない場合や多椎体 の高度破壊が存在する症例では必要かと考えます。

\title{
特発性側彎症に対する我々のアプローチ
}

\begin{tabular}{|c|c|c|c|c|c|}
\hline 山 & 本 & 博 & 司・山 & 田 & 憲 \\
\hline 岸 & & & 浩 - 中 & 川 & 幸 \\
\hline 田 & 村 & 大 & 司・手 & 束 & 昭 \\
\hline 木 & 下 & & 勇・川 & 田 & 尚 \\
\hline 森 & & & 浩・和 & 田 & \\
\hline
\end{tabular}

\section{An Etiological and Therapeutic Approach to Idiopathic Scoliosis}

\section{By}

H. Yamamoto, K. Yamada, H. Kishi, Y. Nakagawa, T. Tamura, A. Tezuka, I. Kinoshita, S. Kawata, H. Mori, N. Wada \& N. Nakaima

Department of Orthopedic Surgery, School of Medicine, Tokushima University

Idiopathic scoliosis is a diagnosis of the curve which etiology is unknown, and is simultaneously considered to be a huge dust box of the diagnosis. This report is on our etiological and therapeutic approach to idiopathic scoliosis.

Equilibrium approach: Among 145 idiopathic cases 109 (75\%) were found to have equilibrium dysfunction in the proprioceptive reflex system (rightening reflex test, writing test) as well as in the optic reflex system (spontaneous nystagmus test, optokinetic nystagmus test). The clinical and experimental investigations indicated that equilibrium dysfunction in scoliosis is caused by a malfunction in a postural reflex system at the brain-stem as well as the peripheral nervous system.

Neurohumoral approach: Idiopathic cases proved to have a marked tendency of emaciation and a low level Basal Metabolic Rate. The results of the tests for endcrine function (growth hormone, pituitary gonatropin, urinary $17 \mathrm{OHCS}$ and ACTH and Metopiron loading test, insulin and suger response) indicated that in the cases with idiopathic scoliosis there exist a hypofunction in the hypothalmo-hypophyseal-endocrine system. As well known, 
postural reflex system is functionally connected to the metabolic regulative system at the hypothalmus and the brain-stem.

These clinical charasteristic facts in idiopathic cases should be reflected to the treatment. Mostly desirable method of the treatment is active correction by the early detection of the curve. We developed "Active Corrective Plaster Jacket" as an early treatment of scoliosis. The purpose of the treatment is to correct the curve actively in accordance with righting reflex of the posture, and to improve the equilibrium function.

Our comprehensive treatment program was presented.

奉柱側彎症の原因にはいろいろあるが，大部分のも のは特発性である．特発性側彎症は原因不明側彎の代 名詞であると同時に，診断上の「くず箱」的存在とも される傾向があり, 貴重な症例がこの混沌の中に埋没 されている.

昭和 40 年以来この 7 年間に 我々のクリニックを訪 れた側彎症例は 356 例であるが，うち 247 例はいわゆ る特発性側彎症であり, 全体の $70 \%$ を占めている.

表 1 Clinical Complications in Idiopathic Scoliosis (161 cases)

\begin{tabular}{|c|c|c|}
\hline Complications & \begin{tabular}{|l|} 
Number \\
of cases
\end{tabular} & \\
\hline $\begin{array}{l}\text { Congenital nystagmus } \\
\text { Athetotic movement } \\
\text { Spastic torticolis } \\
\text { Deafness \& dissiness } \\
\text { Hydrocephalus } \\
\text { Meningitis } \\
\text { A. L. S. } \\
\text { Mental deficency } \\
\text { Others }\end{array}$ & $\begin{array}{r}12 \\
2 \\
2 \\
4 \\
1 \\
1 \\
2 \\
4 \\
3\end{array}$ & Neuropathic \\
\hline $\begin{array}{l}\text { Vertebral epiphyseal } \\
\text { abnormality } \\
\text { Osteoporosis }\end{array}$ & $\begin{array}{l}3 \\
2\end{array}$ & Osteopathic \\
\hline $\begin{array}{l}\text { Congenital chest } \\
\text { deformity } \\
\text { Tuberculosis } \\
\text { Asthma bronchiale }\end{array}$ & $\begin{array}{l}5 \\
3 \\
3\end{array}$ & Costgenic \\
\hline $\begin{array}{l}\text { Anaemia } \\
\text { Hormonal disturbances } \\
\text { Marked emaciation } \\
\text { Proteinuria }\end{array}$ & $\begin{array}{l}4 \\
4 \\
4 \\
3\end{array}$ & Metabolic \\
\hline $\begin{array}{l}\text { Congenital muscle } \\
\text { defect } \\
\text { Arachnodactylia }\end{array}$ & $\begin{array}{l}1 \\
2\end{array}$ & Myopataic \\
\hline $\begin{array}{l}\text { C. D. H. } \\
\text { Leg length discrepancy }\end{array}$ & $\begin{array}{l}4 \\
2\end{array}$ & Static \\
\hline Sclera spot & 3 & \\
\hline $\begin{array}{l}\text { Congenital heart } \\
\text { disease }\end{array}$ & 8 & \\
\hline Total & 84 & \\
\hline
\end{tabular}

しかし，乙れら特発性症例を詳細に観察すると 161 例 中 79 例約半数の屯のに 脊柱彎曲以外に 何らかの合併 症を有している。 そのうちわけは表 1 の如くである が, これらのうち多くのものは neurogenic, osteopathic, metabolic, costgenic, static な諸々の factor として脊柱彎曲の発現に対し, 何らかの関連 性を有することが考えられ得る.

本症の成因追究には subclinical な面での検索が なされなければならない，我々は近年本症に対し平衡 神経学的にこれを追究し, 多数の症例 145 例中 109 例 (75\%) に, 特にその成長期例に, 眼運動系異常を含 む平衡異常を合併することを明らかにした. 臨床的及 び実験的検索より, 本症の平衡異常は脊柱彎曲の発生 進展と密接な関係にあることを証明することができ， その mechanism に扣いて視床下部一脳幹網様体一 脊䯣末梢系が関与していることが推定された.

次に, 我々は特発性側彎症と代謝機能との関係につ いて検討をすすめた．特発性側彎症例には「ひょろ長 いむやしっ子」が多いように思われるが, 患者の体 型, 発育パターンを Rohrer の充実指数を用いて調 べてみると特発性症例には「やせ傾向」が目立ってい る. 基礎代謝率む特発性症例では先天性症例に比べて 明らかに低いレベルにあることが解った. 内分泌機 能検査を行なったが, 特発性側彎症例では Growth Hormon, Gonadtropin の分泌機能に低下があり, 尿中 17 OHCS の bsal level 屯低い傾向にあった. 又, ACTH や Metopiron 負荷により 17 OHCS の 変動をみたところ, 下垂体予備機能の低下を示唆する 症例が認められた. この機能低下は Glucose 負荷に よる血糖変動及び Insulin 分泌変動の 検査によって 屯窅い知ることが出来た. 以上特発性側彎症例には決 して Clear cut なものではないにしても内分泌代謝 機能の低下傾向が認められ，視床下部一下垂体系にお ける代謝調節機能に異常が推定された.

周知の通り, 姿勢と代謝調節機能の間には視床下部 


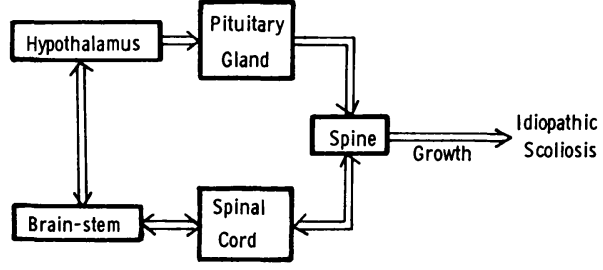

(図 1 )

一脳幹部を中心とした相互の機能的関連がある，侧彎 症の成立にはこの中枢を頂点とした脊柱保持調整機構 における異常が関与するあのと思われる (図 1 ). 勿 論, 症例によってはそのいずれかの部位に重点がおか れているあのがあってよい.

かかる事実は本症の治療面にあ反映されなければな らない, 全身治療として, 栄養の改善, 日常体育活動 の奨励は予防治療の上からも重要である. physical exercise はそれ単独で彎曲の矯正，予防をし得るも のではないにしても補助療法の1つとして欠かすて とは出来ない，我々のとりおこなっている physical exercise は筋力の強化, 彎曲脊柱の mobilisation はもとより特に平衡機能発達の促進の面に重点を置い ている. 従って, 本症の治療にあたっては医師はもと より P. T, 学校教師, 家族等が拹力体制を作る必要 のあることは申すまでもない.

本症の治療法にはいろいろあるが, 早期発見, 早期

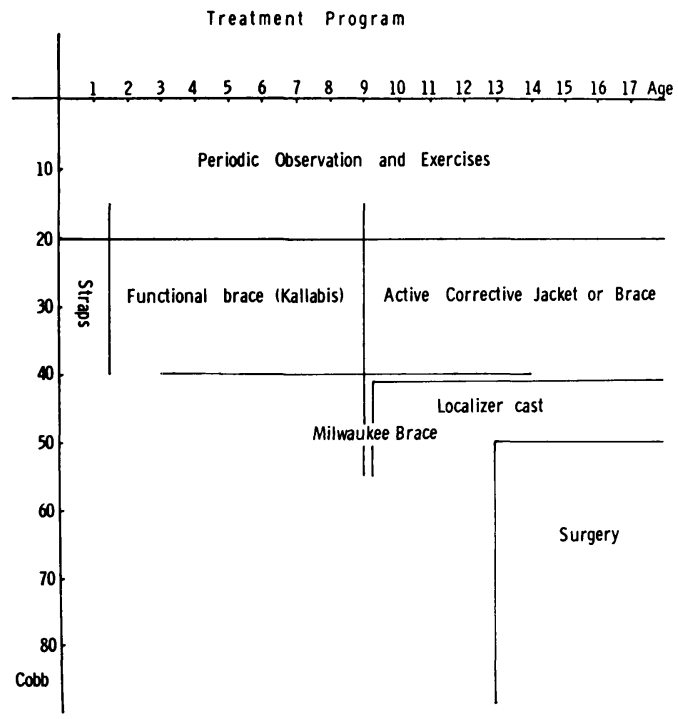

(図 2)
治療による能動的矯正が最も重要であると考えられ る. 我々の治療プログラム (図 2 ) 及び治療成績等に ついては本会の研究会においてその詳細を発表した.

\section{質 問 和歌山医大整形 綿貫 昭則}

(1) 平衡異常が，即ち視床下部の機能異常であると 断定出来る根拠は何でしょうか?.

(2) 内分泌異常を側彎の関係について述べられまし たが Behandlmg の上で，いかに考虑されておられ ますか?.

\section{(1)の返事に対して}

(1) : アドレナリンテストにより 平衡異常が 悪化す るという事実のみで, 視床下部異常と, 断定出来るで しょうか?.

(2) ${ }^{\prime}:$ Edrütz 束の変性と側灣の発生で同側性や程度 等の関係はありましたか?.

質 問兵庫県立のじぎく園 公文裕 idiopathic scoliosis に対する approach の仕方 について，何時む教えて頂いていますが， 2 点を質問 致します.

(1) 眼振, 平衡異常, 代謝機構の低下等の症状が, はっきりしているととが idiopathic scoliosis の本 体であると考えられますのか，または，その様なもの は現在まで一般に云われている，所謂特発性側篎症よ り○○側彎症として別に分類すべきでしょうか.

(2) 脳幹部, 視床下部の障害は, 恐らく先天性にあ ると思いますが，今迄に分類されています infantile， juvernile, adolescent type の発症に対する相関々 係は，どの様に考えていけば良いのでしょうか. 特に 歩行開始前の乳児に強い側彎変形を示すむのにつきま しては?.

\section{質 問 長崎大学整形外科 䅖山富太郎}

(1) 一口に平衡機能障害と云っても, spinal reflex レベル, tonic reflex レベル, さらに上位中枢レベル のどのレベルに障害があるかを決定することは困難だ と考えられるが, 視床下部にその因を求めた場合, そ れが organic なものか, functional なものかの相違 についてお教え願いたい.

(2) 特発性側彎症患者の乳児期における運動発達状 態がわかっていたらお教え願いたい. 
回 答

質問(1) 和歌山大の先生に対して

(A) 視床下部の 関与の 可能性については 臨床的に O. K. N. の Ad. 負荷による反応パターン並びに動物 実験による脳幹部の stereotaxic destruction による 脊椎変形と障害部位 (Schütz 系) の関係等も重要な データーであった.

(B) 視床下部異常に 代謝の関連は更に今後の 臨床 的, 実験的検討が必要であります. 治療に関してもこ れの十分な研究の後に見い出しうる可能もあるかと思 われます.

\section{質問 2 （公文先生に対して）}

(A) 側彎性は一次的な平衡異常のみならず, 脊椎保 持調節機構のいづれに原因があっても結果される1つ の臨床的症候と思われる.

B) 例えば congenital な dysplasia が中枢にあっ たにせよ, scoliosis の発現には成長に伴う増悪が重 要な因子と思われます.

質問 3 に対して

中枢破壊実験の際，破壊側とカーブの laterality は今後の重要問題と思われる.

\title{
比較的簡単な頸部空気脊髄腔造影法
}

\section{（第 2 報）}

山口大学医学部整形外科教室

小田 清 彦・服部奨

奥山暁

\section{A New Method of Simple Cervical Air Myelography. (The second report)}

By

\author{
K. Oda, S. Hattori \& A. Okuyama \\ Department of Orthopedic Surgery, Yamaguchi \\ University School of Medicine
}

We describe a new method of cervical air myelography which has been made with 20$40 \mathrm{ml}$ of air using the catheter.

This method has been performed on 52 patients with various cervical abnormalities. It can be performed simply and safely.

Advantages and disadvantages of this method on the cervical spondylosis were discussed in comparison with conventional oil myelography.

This technique is especially useful in demonstrating the spinal canal stenosis and should be used more widely in cervical lesions.

第四十一回本学会では, 私達は硬膜外麻酷用カテー テルを使用する比較的簡単な頸部空気脊髄腔造影術の 方法を主に紹介した．今回は私達の方法により頸部脊 椎骨軟骨症, 後縱勒带骨化症, Root avulsion, 脊䯣 腫癔, 上位頸椎疾患など 52 例に 空気脊䯣腔造影術を 行なった．乙れら咨患の所見と, 頸部脊椎骨軟骨症に

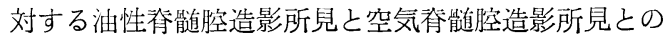
対比, 及び頸部脊椎骨軟骨症の油性脊髄腔造影所見の 解勫に参考となる事項を紹介する.

方法

第一報と重複するので，簡単に述べる．持続硬膜外 